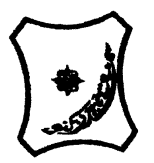

Bayero Journal of Pure and Applied Sciences: 10(1): 536 - 540

ISSN $2006-6996$

\title{
URBANIZATION AND CLIMATE CHANGE: THE ROLE OF ROAD TRANSPORT IN CARBON DIOXIDE EMISSION IN KANO METROPOLIS, NIGERIA
}

\author{
Usman, S.U. ${ }^{1 *}$, Abdulhamid, A.I. ${ }^{1}$, Gwadabe, S. ${ }^{3}$, Usman, A.K. ${ }^{2}$, Isah, B. ${ }^{4}$ Mallam, I. ${ }^{1}$ \\ ${ }^{1}$ Department of Environmental Science, Federal University, Dutse, Jigawa State \\ ${ }^{2}$ Department of Geography and Environmental Management, Ahmadu Bello University, \\ Zaria, Kaduna State \\ ${ }^{3}$ Department of Geography, Sa'adatu Rimi College of Education, Kano, Kano State \\ ${ }^{4}$ Department of Primary Education Studies, Isa Kaita College of Education, Dutsin-ma, \\ Katsina State \\ ${ }^{*}$ Corresponding Author: saniuusman@gmail.com, (+2348067996739)
}

\section{ABSTRACT}

Large cities are characterized by concentration of large number of people and centralization of commercial activities around their cores. These necessitate concentration of automobiles and consequently, emission of large amount of carbon dioxide $\left(\mathrm{CO}_{2}\right)$ into the atmosphere. This study aims to estimate the average amount of $\mathrm{CO}_{2}$ being emitted hourly by automobiles in Kano Metropolis, Nigeria. The related objectives include; determining automobiles hourly average density on the city's roads, estimating $\mathrm{CO}_{2}$ emission from respective categories of automobiles and examining the situation against $\mathrm{CO}_{2}$ abatement measures submitted by the Federal Government of Nigeria to the United Nations Framework Convention on Climate Change. Short period traffic count at various traffic corridors of the city was used to determine automobiles' average density per hour and United States Environmental Protection Agency method was used in estimating $\mathrm{CO}_{2}$ emission from automobiles. Results revealed the following emissions in metric tonnes per hour; 15.75 from cars and buses, 6.08 from tricycles and 0.56 from lorries. These give a combined hourly emission of 22.39 tonnes. $\mathrm{CO}_{2}$ abatement measures identified are expansion of roads and construction of flyovers to decongest traffic. It is recommended that efficient public urban mass transit that involves low carbon emission should be provided and individual car usage should be discouraged.

Key words: $\mathrm{CO}_{2}$ abatement, automobile density, climate change, global warming, greenhouse gases

\section{INTRODUCTION}

Urbanization and climate change are intricately connected through emission of greenhouse gases (GHG) from human activities that characterize modern cities. It has been observed that growth of cities beyond walking scales and concentrations of commercial activities in central business districts (CBDs) necessitate widespread use of automobiles in order to transport people and goods within cities (World Business Council for Sustainable Development, 2002). This leads to considerable emission of greenhouse gases (GHGs) especially carbon dioxide $\left(\mathrm{CO}_{2}\right)$ into the atmosphere.

Some GHGs occur naturally in the atmosphere, which include carbon dioxide $\left(\mathrm{CO}_{2}\right)$, methane $\left(\mathrm{CH}_{4}\right)$, nitrous oxide $\left(\mathrm{N}_{2} \mathrm{O}\right)$, sulphur dioxide $\left(\mathrm{SO}_{2}\right)$, water vapour and ozone $\left(\mathrm{O}_{3}\right)$. Others are only produced and emitted through human activities. These include chloroflourocarbons (CFCs), hydroflourocarbons (HCFCs), perflourocarbons (PFCs), sulphur hexafluoride $\left(\mathrm{SF}_{6}\right)$ and nitrogentriflouride $\left(\mathrm{NF}_{3}\right)$ (Wallington,
Srinivasan, Nielsen \& Highwood, 2004). Presence of both types of gases in the atmosphere allow unrestricted passage of incoming solar radiation but restrict the passage of terrestrial infrared radiation (heat) radiated back from the Earth's surface. This is known as greenhouse effect. Increase in both types of GHGs through human activities is believed to be causing unprecedented accumulation of heat in the atmosphere which is reradiated back to the Earth's surface resulting into global warming. There is broad consensus among scientists that it is this human-induced global warming that has been causing recent changes in global climate patterns, which are referred to as climate change (Intergovernmental Panel on Climate Change [IPCC], 2007).

Review of literature for this study indicates a relationship between city size (in terms of human population) and the amount of $\mathrm{CO}_{2}$ emitted by individual vehicles. 
For instance, Kakouel, Vatani \& Bin Idris (2012) revealed that in Tehran (Iran), with population of about 9 million, a private car emits 17.18 tonnes of $\mathrm{CO}_{2}$ annually. Magalhaes \& DuranOrtiz (2009) revealed that annually, a light vehicle emits 6.2 tonnes in Brasilia (Brazil) with population of 4.2 million while a similar vehicle emits 4.2 tonnes in Curitiba (Brazil) with population of 1.8 million. In Mekelle City (Ethiopia), with population of about 300,000 people, a light vehicle emits 0.26 tonnes annually (Gebre, 2016). These corroborate the findings of the International Energy Agency (1997) that population and degree of urbanization are among the most important factors influencing $\mathrm{CO}_{2}$ emission.

Therefore, for any $\mathrm{CO}_{2}$ abatement measure to be efficient there must be proper understanding of emission sources and magnitude of emission from each source. Hence, estimating $\mathrm{CO}_{2}$ emission form vehicles in a large city like Kano is an important step towards providing a comprehensive $\mathrm{CO}_{2}$ emission inventory of the city. Such inventories are much needed to generate worldwide estimates of city scale emissions and assess air quality and fuel consumption in the city which will enable decision makers to manage the emissions. This is because cities have been identified as key to reducing GHGs emissions since more than $70 \%$ of global energy-induced emissions are generated there (Bulkeley, 2013). This study aims to estimate the amount of $\mathrm{CO}_{2}$ emitted by road traffic in Kano metropolis. The related objectives include determining average hourly automobile density on the city's roads, estimating $\mathrm{CO}_{2}$ emissions from respective automobile categories and examining the situation against the backdrop of $\mathrm{CO}_{2}$ abatement measures of the Federal Government of Nigeria.

\section{MATERIALS AND METHODS}

\section{Study area}

Kano metropolis is located between Latitudes $8^{\circ} 25^{\prime} \mathrm{E}$ and $8^{\circ} 40^{\prime} \mathrm{E}$ and Longitudes $11^{\circ} 53^{\prime} \mathrm{N}$ and $12^{\circ} 40^{\prime} \mathrm{N}$. It occupies more than 499 square kilometres, has population of over 4 million people, 43 existing market places, over 400 privately owned manufacturing industries and road length of over 3,112 kilometres (Maigari, 2014; Maigari, 2016). The city falls within tropical wet and dry (Aw) climate type based on Koppen's classification.

In 2016, Kano metropolis was ranked number 115 on the list of 1,017 largest built-up urban areas in the world. In terms of urban population density, it has 14,600 persons per square kilometre and was ranked number 102 in the world (Demographia, 2016).

Types and sources of data

Short period traffic count was used in collecting data on hourly number of three categories of automobiles on the city's roads. These are cars (private cars and taxis) and buses, tricycles and lorries (including articulated lorries). The count was conducted at $8: 30$ to $9: 30$ am and 5:30 to 6:30 pm from 9 to 11 March, 2017 at six locations representing high, moderate and low traffic density areas. These are Dangi roundabout and Ibrahim Taiwo Road/Post Office (high density), Zoo Road/GidanBuhari and Kwanar Sabo Junction (medium density) and Government House and Daula Roundabout (low density). Short period traffic count is an effective way of estimating vehicles on a given road at a given period (Musa \& Garba, 2013), especially when official figures are not available.

Other data used include fuel consumption (in litres per kilometre) for the three categories of vehicles; 0.034 litres for a 4 -stroke tricycle (Vergel \& Tiglao (2013), 0.1125 litres for an average light duty car (United States Environmental Protection Agency [USEPA], 2011) and 0.35 litres for a lorry (Calculation of $\mathrm{CO} 2$ emissions, n.d.). Amounts of $\mathrm{CO}_{2}$ (in grams) emitted by burning a gallon of gasoline $(8,887 \mathrm{~g})$ and a gallon of diesel $(10,180 \mathrm{~g})$ were obtained from USEPA (2011). In addition, $\mathrm{CO}_{2}$ emission from vehicles was estimated using the USEPA (2011) method determined as:

Fuelconsumption per km

1 gallon
Carbon dioxide emission per $\mathbf{k m}$
Amountof carbondioxide per gallon

From equation 1 , carbon dioxide emission per $\mathrm{km}$ is determined as:

$\frac{\text { Fuel consumption per } \mathbf{k m}}{1 \text { gallon }} \mathrm{X}$

Amount of carbondioxide per gallon..... (2)

From this, hourly average $\mathrm{CO}_{2}$ emission of each category of vehicles (moving at an average speed of $30 \mathrm{~km}$ per hour) in the study area determined as:

Carbon dioxide emission per $\mathbf{k m} x$

average speed $(30$

$x$ number of vehicles.

$\mathrm{km} / \mathrm{h}$ )

Furthermore, information on the Federal Government of Nigeria's proposed projects on $\mathrm{CO}_{2}$ emission abatement contained in the first and second communication of the government to the United Nations Framework Convention on Climate Change (UNFCCC) was used in discussing the results. 


\section{RESULTS AND DISCUSSION}

Result of short period traffic count is presented in Table 1. It is clear from the table that cars/buses and tricycles comprise the bulk (98.56\%) of automobile density in the study area. Tricycles have the highest average density closely followed by cars/buses while lorries have the lowest. The table also shows that traffic density is not evenly distributed in the study area. High traffic density areas coincide with areas of high commercial activities.

Table 1: Average Automobile Density per Hour in the Study Area

\begin{tabular}{llll}
\hline Area & \multicolumn{3}{c}{ Category of vehicle } \\
& Cars/buses & Tricycles & Lorries \\
High density areas & 3,086 & 3,490 & 31 \\
Medium density areas & 2,099 & 3,093 & 24 \\
Low density areas & 772 & 1,025 & 5 \\
Average & 1,986 & 2,536 & 20 \\
Percentage & $\mathbf{4 3 . 7 3}$ & $\mathbf{5 5 . 8 3}$ & $\mathbf{0 . 4 4}$ \\
\hline
\end{tabular}

Source: Authors' Field work 2017

In its effort to mitigate climate change through $\mathrm{CO}_{2}$ emission abatement measures, the Federal Government of Nigeria identified traffic congestion as one of the factors that aggravate $\mathrm{CO}_{2}$ emission. Thus, in order to decongest the Nigerian roads and reduce $\mathrm{CO}_{2}$ emission, the government in its first communication to the UNFCCC proposed substitution of small vehicles on Nigerian roads with mass transit buses and rail (Federal Republic of Nigeria, 2003). However, results of this study indicate that fourteen years after submitting the document, small vehicles are still the most widely used mode of transport in the study area. This coupled with the fact that there is total absence of intra-city rail and public mass transit bus services in the study area and almost all Nigerian cities imply that the Federal Government's $\mathrm{CO}_{2}$ emission abatement measure involving substitution of small vehicles with rail and mass transit buses is far from being realized. It is only in Lagos that Bus Rapid Transport (BRT) was tested (Federal Republic of Nigeria, 2014).

In terms of uneven distribution of traffic density in the study area where high traffic density areas coincide with areas of high commercial activities, this tends to result in slowing down of traffic flow, frequent stopping and idling. Research has established that slow traffic flow and idling result in increase in fuel consumption and $\mathrm{CO}_{2}$ emission by $10 \%$ or more (Asian Development Bank, 2010). This means that the more the traffic congestion the higher the $\mathrm{CO}_{2}$ emission from vehicles. Nigeria's first communication to UNFCCC identified this problem in some Nigerian cities which include Lagos, Port Harcourt, Abuja and Kano (Federal Republic of Nigeria, 2003). Subsequently, the second communication to the UNFCCC viewed road expansion for easy vehicular movement as a solution to the problem (Federal Republic of Nigeria, 2014). Therefore, the efforts of both the federal and Kano State governments in decongesting the Kano metropolitan roads through roads expansion and construction of flyovers at major traffic corridors are good for $\mathrm{CO}_{2}$ emission abatement and consequently climate change mitigation.

Result of estimation of $\mathrm{CO}_{2}$ emission by vehicle category was obtained using equation 2 and is presented in Table 2. It can be seen from this table that of all the vehicle categories considered in this study, lorry has the highest rate of $\mathrm{CO}_{2}$ emission per kilometre. This is attributable to the fact that it has the highest fuel consumption per kilometre and that diesel has higher carbon content than gasoline. Thus, substituting lorries with rail or pipeline (in terms of transportation of gaseous and liquid fuels) will be a good climate change mitigation measure.

Table 2: Estimated $\mathrm{CO}_{2}$ Emission per Kilometre

\begin{tabular}{ll}
\hline Vehicle category & $\mathrm{CO}_{2}$ emission/km (in grams) \\
Car/bus & 264.49 \\
Lorry & 942.59 \\
Tricycle & 79.94 \\
\hline
\end{tabular}

Substituting the average number of vehicles (as shown in Table 1) and $\mathrm{CO}_{2}$ emission per kilometre (as shown in Table 2) for each category of vehicles in equation 3 while assuming the average speed of vehicles in the metropolis to be 30 kilometres per hour yield the following results: 1,986 cars/buses emit
$15,758,314 \mathrm{~g}$ (15.75 tonnes) of $\mathrm{CO}_{2}$ per hour, 2,536 tricycles emit $6,081,835.2 \mathrm{~g}$ (6.08 tonnes) of $\mathrm{CO}_{2}$ per hour and 20 lorries emit $565,554 \mathrm{~g}$ (0.56 tonnes) of $\mathrm{CO}_{2}$ per hour. These give a combined average hourly $\mathrm{CO}_{2}$ emission of 22.39 tonnes in the metropolis. 
These indicated that large amount of $\mathrm{CO}_{2}$ is emitted by road transport in the study area. It is our belief that the amount of $\mathrm{CO}_{2}$ emitted by road transport in the metropolis is more than what was estimated in this study because of the following reasons. One because motorcycles which form an integral part of road transport in the study area are not included in this study. Two because road worthiness of vehicles is not adequately observed in the country due to which most of the vehicles plying Nigerian roads are either old or poorly maintained. Research has established that such vehicles are associated with high $\mathrm{CO}_{2}$ emissions (Gorham, 2002). This suggests that there is still a long way to go for the Nigeria's $\mathrm{CO}_{2}$ emission abatement measure involving setting standards for importation and use of vehicles (Federal Republic of Nigeria, 2014) to be achieved.

Conclusion

From the results of this study it is concluded that continuous physical expansion of the study area and increase in population will always give rise to increase in number of small vehicles in the area and consequently, increase in $\mathrm{CO}_{2}$ emission, as far as larger modes are not provided. Even though small vehicles have relatively small $\mathrm{CO}_{2}$ emission rates yet, with their large number plying the city's roads, they are capable of emitting considerable amount of $\mathrm{CO}_{2}$. Therefore any climate change mitigation measure in the study area especially the one involving $\mathrm{CO}_{2}$ emission abatement that does not involve tackling urbanization with respect to

\section{REFERENCES}

Asian Development Bank. (2010). Reducing carbon emissions from transport projects. (Report No. EKB: REG 201016). Retrieved on $5^{\text {th }}$ February, 2017 from

https: / /www.adb.org/sites/default/fil es/evaluation_document/35942/files/e kb-reg-2010-16-0.pdf

Bulkeley, H. (2013). Cities and climate. New York: Routledge

Calculation of $\mathrm{CO} 2$ emissions (n.d.) Retrieved on $3^{\text {rd }}$ March, 2016 from https://people.exeter.ac.uk/TWDavies /energyconversion/calculation $\% 20$ of $\% 20 \mathrm{CO}_{2} \% \mathrm{em}$ issions\%20fuels.htm

Demographia. (2016). Built up areas or world agglomerations. $\left(12^{\text {th }}\right.$ ed), Belleville, USA, Author. Retrieved on $20^{\text {th }}$ March, 2017 from www.demographia.com/abworldua.pdf

Federal Republic of Nigeria. (2003). Nigeria's first national communication under the United Nations Framework Convention urban transportation will be a feeble and ineffectual one. It is recommended that adequate public urban mass transit in form of buses with low $\mathrm{CO}_{2}$ emission should be provided and use of private cars should be discouraged in order to reduce the number of small vehicles in the city. Standards in terms of age of vehicles, fuel economy and $\mathrm{CO}_{2}$ emission should be strictly enforced. Given the enormity of $\mathrm{CO}_{2}$ being emitted from the city's road transport, its implications in accentuating climate change and deterioration of air quality in the city, $\mathrm{CO}_{2}$ emission abatement measures in cities should be given a substantial share from the nation's Ecological Fund. New parts of the city should be designed and the existing parts should be redesigned in such a way that activities that attract traffic are decentralized in order to reduce traffic congestion. Pedestrian and bicycle lanes should be provided so that walking and bicycling could be encouraged among the city's dwellers.

Authors' Contributions: Each of the authors participated in the vehicle count survey (primary data collection). Usman, S.U., Abdulhamid, A.I. and Gwadabe, S. collected the secondary data. Usman, S.U., Isah, B. and Mallam, I. performed the data analyses and Usman, S.U., Abdulhamid, A.I and Usman, A.K. drafted the manuscript.

Conflict of Interest: The authors declare no conflicts of interest among them in whatever form.

on Climate Change. Abuja: Federal Ministry of Environment. Retrieved from

unfcc.int/resource/docs/natc/nignc1.p df

Federal Republic of Nigeria. (2014). Nigeria's second national communication under the United Nations Framework Convention on Climate Change. Abuja: Federal Ministry of Environment. Retrieved from unfcc.int/resource/docs/natc/nganc2.p df

Gebre, T. (2016). $\mathrm{CO}_{2}$ emission level in urban transport of Mekelle City, Ethiopia. Journal of Environmental and Earth Science 6(1), 64-71

Gorham, R. (2002). Air pollution from ground transportation: An assessment of causes, strategies and tactics and proposed actions for the international community. New York: United Nations. Retrieved from www.un.org/esa/gite/csd/gorham.pdf 
Special Conference Edition November, 2017

International Energy Agency. (1997). Indicators of energy use and efficiency: Understanding the link between energy use and human activity. Paris: OECD

Intergovernmental Panel on Climate Change. (2007). Fourth assessment report. Geneva: World Meteorological Organisation. Retrieved on $11^{\text {th }}$ August, 2009 from https: / /www.ipcc.ch/pdf/assessmentreport/ar4_wg2_full_report.pdf

Kakouel, A., Vatani, A. \& Bin Idris, A.K. (2012). An estimation of traffic related $\mathrm{CO} 2$ emissions from motor vehicles in the capital city of Iran. Iranian Journal of Environmental Health Sciences \& Engineering (9), 13 http://www.ijehse.com/content/9/1/1 $\underline{3}$

Magalhaes, F. \& Duran-Ortiz, M. (2009, October 18-22). Low carbon cities: Curitiba and Brasilia. Paper presented at the Forty Fifth International Society of City and Regional Planners Congress. Porto, Portugal. Retrieved on $6^{\text {th }}$ July, 2012 from

www.isocarp.net/data/case_studies/14 92.pdf

Maigari, A.I. (2014). How far is too far? The facts and figures on human population in Kano State. International Journal of Humanities and Social Science Innovation 3(4), 61-64

Maigari, A.I. (2016). Road Network: The silent treasures of Kano metropolis.
International Journal of Innovation Environmental Studies Research 4(1), 1-8

Musa, I.J. \& Garba, I. (2013). Application of short period traffic count to estimate daily traffic flow in Ahmadu Bello University Zaria, Nigeria. Zaria Geographer 20(1), 130-134

United States Environmental Protection Agency. (2011). Greenhouse gas emission from a typical passenger vehicle. Paper No. EPA-420-F-11-041. Ann Arbor, USA: Author

Vergel, K.B.N. \& Tiglao, N.C.C. (2013). Estimation of emissions and fuel consumption of sustainable transport measures in Metro Manila. Philippine Engineering Journal 34(1), 31-46

Wallington, T.J., Srinivasan, J., Nielsen, O.J. \& Highwood, E.J. (2004). Greenhouse Gases and Global Warming. In Sabljic, A. (ed) Encyclopaedia of Life Support System (EOLSS), Developed under the Auspices of the UNESCO, Oxford: Eolss Publishers

World Business Council for Sustainable Development. (2002). Mobility 2001. Cambridge, USA: Massachusetts Institute of Technology and Charles River Associates Incorporated. Retrieved on $20^{\text {th }}$ January, 2010 from web.mit.edu/aeroastro/sites/waitz/pu blications/WBCD.report.pdf 